\title{
Establishing Post Logistics by Spinning-off Logistic Business Unit
}

\author{
Hana Suryana, Lili Adi Wibowo \\ Universitas Pendidikan Indonesia \\ Bandung, Indonesia \\ hanasuryana.upi12@gmail.com
}

\begin{abstract}
Logistics is a vital activity, almost every aspect of human life is influenced by the logistics process, either directly or indirectly. This study is designed to assess the capacity and capability of PT Pos in managing the logistics business. Descriptive and data analysis method has been chosen to provide the profile, with SWOT analysis used to identify opportunities and threats in the firm's managing logistics business. Object in this study is the logistics business unit of PT Pos that will be spun-off into a subsidiary company, Post Logistics. Results of the study portrayed business process as the key success factor that had the highest weight, with other variables having various weight. The scope of weighting related to the readiness of PT Pos in logistics business as a subsidiary, are: freight forwarding, transporting, warehousing, providing service as regulated agent. In addition, it is necessary to have an in-depth knowledge of the capabilities of each group of resources, which are the location of the company, facilities and infrastructure, and human resources.
\end{abstract}

\section{Keywords: Capability, Capacity, Spin-off, SWOT Analysis}

\section{INTRODUCTION}

Logistics is one of the most vital activity, as a component incurring one of the highest cost of all organization's expenses, in both profit-oriented and nonprofit organizations. Competitiveness of companies are affected by the cost and supply chain performance, and therefore, depends on the overall logistics environment. Given a very large role in the economic activity in general, logistics services industry market grows along with economic growth.

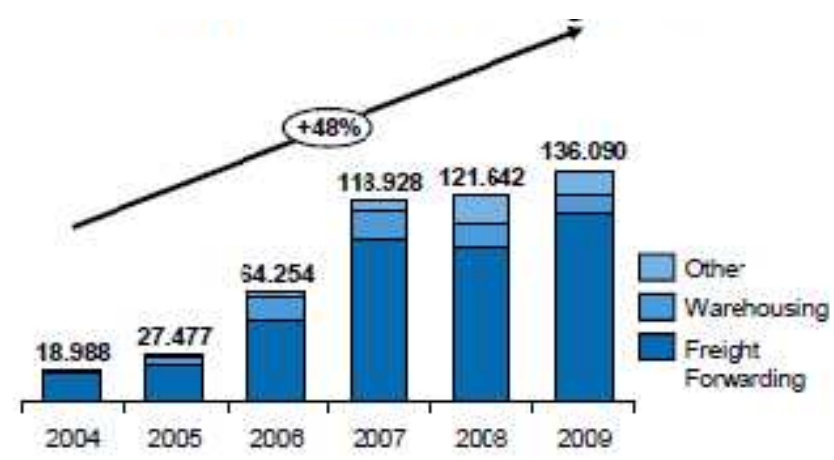

1. Source: Booz\&Co.,[1].
In the scale of Asia Pacific, the average growth of the logistics business market for five years 2008-2013 is estimated at approximately $10.1 \%$ per annum (Data monitor, 2009), with a key sector for future markets such as retail, automotive, and consumer goods. In national scope, logistics costs about $24 \%$ of GDP Ella Syafputri [2]. Illustratively, in 2011, with GDP valued at Rp7.427, 1 trillion [3], the logistics market potential worth Rp1.782, 5 trillion, a huge figure for an industry.

Legally, the government actually have arranged a very strategic move for the postal industry to take advantage of (i.e to provide logistic and payment system nationwide) [4]. PT Pos strategic role as state-owned logistics service provider could strengthen national connectivity Indonesia in the forum of Indonesian Logistics Community Services.

Although logistics is the main line of PT Pos business, it has not provided maximum contribution to the revenues of PT Pos. With a sizable logistics market potential in Indonesia, PT Pos relished only a fraction of the market share, Frost and Sullivan [5] define the market share of PT Pos currently below 1\%. On the other hand, PT Pos Revenue growth in the logistics business is very potential, averaging about $48 \%$ in the period of six years (2004-2009) as shown in the Figure 1. National Logistics costs are 24\% of GDP, the total market 3rd Party Logistics (3PL) amounting to Rp149 trillion,

It is both a potential and challenging market. Logistics by nature is a set of value-added activities that include production, location, time, and control of all elements of the supply chain. Accordingly, s customer based supply-chain management is considered a total solution to meet the needs of the customer. Whereas appropriate service for these solutions is warehousing, transportation, freight forwarding, as well as a Regulated Agent in Indonesia.

Despite having great potential, logistics business is a business tangled in high level of complexity, demanding special competence and flexibility, activities loaded with countless red-tapes and regulations. Not to mention, it now faces the challenges of technology advancements. Dedicated business management is one of the critical success factors for this business.

PT Pos, as the state-owned postal operators, has the capacity and capability to exploit the business potential of logistics as well as play an active role in solving problems of nationwide logistics. However, there are a few things that need attention related to logistics business management, namely:

- Flexibility of resource management, including procurement processes, customer management and partnership. 
Decisions about resource use to manage the business often must be done with a very short and simple procedure.

- Some logistic activities require complex regulations and procedures

From the background and the identification of these problems then this study will answer questions relating to the following issues:

- What is the profile of PT Pos - regarding its capacity and capability in managing the logistics businesses?

- What kind of business model that can meet the demands of the market and the dynamic logistics industry?

\section{LITERATURE REVIEW}

Logistics is one of the industries characterized by a dynamic market, caused by the intense diversity in this industry. Therefore, logistics service providers need to utilize their resources optimally and be as agile as possible to adapt to that market dynamics. The primary concept used to discuss the issues in this article are related to dynamic capabilities [6] and marketing dynamics.

\section{A. Dynamic capabilities}

The concept of dynamic capabilities [7] arises from the concept of resource-based that resource-based view-RBV Wernerfelt $[8,9$, 10]. Asset and infrastructure are very important to provide good services [11]. Resources that are simultaneously valuable, rare, cannot be imitated, and cannot be replaced, can be a source of superior performance, which in turn creates a competitive advantage for the firm [11].

Helfat and Petaraf [10], also describe, dynamic capabilities as the capacity of the organization to create, improve, and modify its resources for a particular purpose. Resource includes all tangible assets, intangible assets, and human resources. While capability is a set of specific processes and can be identified as product development, strategic decision, and alliances [12]. It is suggested that dynamic capability be operated through the skills, resources, and functional competencies [6].

In the context of marketing, the level of moderate market dynamics, dynamic capabilities resemble the traditional concept of routines. While in high volatility markets, dynamic capabilities are characterized by simple properties, a process that is experiential and vulnerable, with unpredictable results [12].

\section{B. Logistic Services in the framework of Competitive Advantage}

Logistics originally as a liaison between production and consumption [13]. Nevertheless, we realize that the role of logistics is not that simple, especially associated with the concept of the value chain [14].

The competitive advantage cannot be understood simply by looking at a firm as a whole. Competitive advantage is formed by discrete activities of the company in designing, creating marketing, delivering, and providing support services for its productions. Each of these activities can contribute to the cost leadership position and create a basis of differentiation. Cost advantage, for example, can be awakened through sourcing with a competent distribution system, an effective assembly process, or the utilization of superior sales people.
Differentiation can be awakened from a variety of factors that can create unique high-quality materials such as procurement, systems responder's order, or excellent product design [14].

A company's value chain is part of a large system of activities, which [14] often refers to it as the value system, as illustrated in Figure 2. In the picture, it illustrates the creation of competitive advantage in terms of value systems involving other parties. The conception of 3PL, companies have to improve their competitive advantages and associate it with its competence [

\section{Logistics Service on Marketing Perspective}

Logistics is a vital kind activity. Almost every aspect of human life is influenced by the logistics process, either directly or indirectly [16].

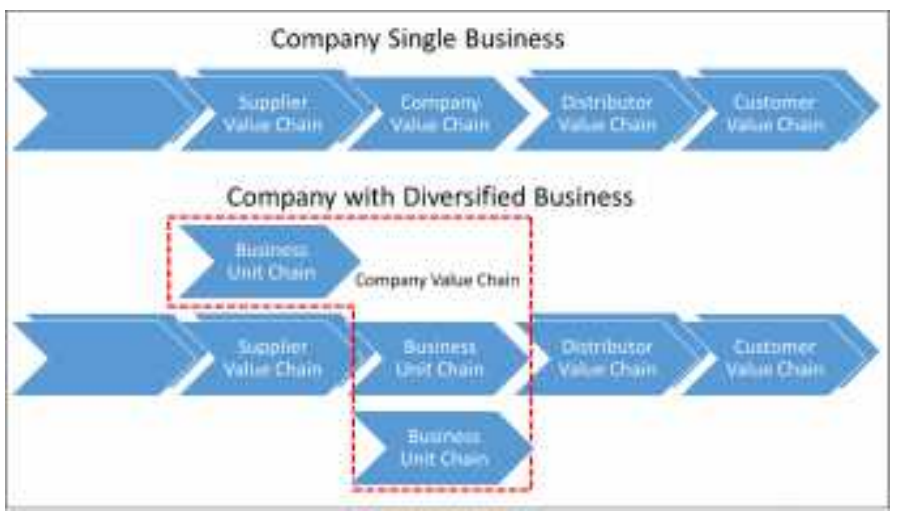

Fig. 2. Above is related to Value Chain, Poorter (2005, page 35)

In the concept of marketing, physical distribution as part of logistics, is one of the vital activities for customer service[17]. There is a relationship between the physical distribution services, customer satisfaction, and purchasing decisions by customers [18]. However, quality of logistics services is not merely physical distribution, it also includes other elements of customer service, which often referred to as customer service in marketing [19]. While Ellinger [20], showed a positive effect of interdependence between marketing and logistics functions to company performance. Devolution (outsourcing) physical distribution function to external (third-party logistics service provider-3PL) has been the trend in the market [21]), because it can increase the capability and performance of logistics companies through the 3PL expertise [15]. Outsourcing logistics activities are intended to enable companies to focus on the customer. This is due to the logistics activities not being a core competencies' of corporate activity, even though it has a huge effect on customer satisfaction (e.g. the issue of timeliness demand) . Many companies that focus on their own competencies possess competitive edge [8, 9, 22]. Focus on customers and building customer relationships are essential for companies to maintain customers [23, 24, 25]. Relationships with customers enables the company to process the important information about customer needs to design and manufacture products that meet the aspects of quality, lead time, and cost efficiency [26].

\section{RESEARCH METHODOLOGI}

Descriptive analysis: by assessing all the data of logistic business profile at PT Pos, using SWOT analysis and literature review related to logistics business, strategic management journal, and references relevant to the unit analysis. 


\section{DISCUSSION}

\section{Object Research Studies}

Logistics is one of the lines of business at PT Pos. To provide a clearer picture about the business profile and capacity to manage the business, SWOT analysis can be applied to identify the capacity and capability as well as opportunities and threats to the post offices in managing the business.

SWOT analysis is used to examine the structure of an industry or a corporate environment involving two environmental compartments; (1) Internal Environmental, which is expressed in a strengths' analysis and weaknesses. (2) External Environment is identified based on opportunities and threats. The internal and external analysis of Logistic business of PT Pos which will be spun-off, are described as follows:

\section{E.. SWOT Analysis}

\section{1) Strengths}

Some power (strengths) of PT Pos that can be identified are as follows:

a) Possessing the fundamental infrastructure which has been used for the logistics services, such as:

- $\quad$ Services point and transportation, as a basic prerequisite in organizing logistics services.

- Information technology for integrating logistics business processes.

b) Possessing other resources such as financial, human resources, some infrastructure, including the market, location and business partners. PT Pos previously has organized logistics services so that resource requirements for the provision of logistics services is relatively fulfilled.

c) Experienced in managing logistics services. Experience is an invaluable intangible capital as it is one of the competencies that will support the success of the logistics business. PT Pos has been on several occasions handled the logistics business for big clients, such as:

- Transportation services for Suzuki Int'l. Publishing house Tempo, etc.

- Warehousing services for Telkomsel, Kisel, etc.

- Freight forwarding services (including customs clearance) for the distribution of imported items owned by Pertamina.

a) Brand image of PT Pos has been recognized in the industry and the market. PT Pos has a strong image in the community and industry, so that market penetration of the brand will be relatively easy, quick and efficient. Asset of PT Pos, above mentioned in line with the needs of phisical distribution as the power of marketing [27, 28].

\section{2) Weaknesses}

The weaknesses analysis highlights of internal weaknesses, both system resources and PT Pos in managing the logistics business. Weaknesses identified include:

a) The main resource logistics business; especially technology, some tools, and systems; is still limited. To focus on the logistics business, PT Pos still have to invest in tools / equipments technologies, and systems. Funds for these investments should be able to increase its capital in order to generate revenue.

b) The existing Organizational structure is rigid. Rules and bureaucracy in the procurement of goods / services, financial management and human resources, could not follow the dynamics of the industry. Meanwhile, the logistics industry demands high business adaptability and flexibility.

\section{3) Opportunities}

Opportunity analysis identify the opportunities that can be exploited by PT Pos. Logistics business is very potential, its growth in line with economic growth and a large proportion of GDP [29]. Opportunities include:

a) Government policy of improving connectivity, both domestically and internationally. which requires the support infrastructure and logistics services.

b) Inspection Agency Policy (Regulated Agent-RA) by the government to open opportunities for post offices to become Inspection Agency in order to strengthen the competitiveness of its business (with an efficiency that is formed due to RA).

c) Policy of strengthening the non-oil commodity exports and domestic trade growth provides a greater opportunity for the provision of infrastructure and logistics services.

d) Changes in the retail business requires logistics support services, and unlock the potential of the logistics market.

\section{4) Threats}

The opposite of opportunity, threat analysis identifies various threats from the external environment to PT Pos. Identified threats include:

a) Because of the large and fragmented logistics market, many players who are also interested can also jump in the logistics business. Not only domestic players, but also global operators. This will spark a competition of market share, as well as an increase in employee turnover, especially for managerial level and above.

b) Technological changes in business processes due to market demands and industry dynamics. This change of course have an impact on the cost and time, as well as the adjustment process.

c) Infrastructure and transport management in Indonesia is less than adequate, which affects the performance of this industry

\section{F. Profile of the capacity and capability}

Internal resource-based approach can help in analyzing the operational readiness of PT Pos in managing the logistics business. This approach was first performed with the capacity and capability assessment of PT Pos.

The capacity and capability profile of PT Pos associated with each line of business logistics is described in three groups of resources, location, facilities and infrastructure, and human resources. The third profile resources are described as follows:

1) Location. PT Pos has geographically dispersed locations, covering all provincial cities to the smallest location points of the territory (district and village). PT Pos even have operational offices in strategic knots of logistics networks, such as airports and ports. PT Pos also have the nodes as mail processing center for the distribution of postal items. 
2) Facilities and infrastructure. Facilities and infrastructure is a vital resource for a logistics service provider. Include warehouse facilities and infrastructure and supporting facilities, consisting of cars, motorcycles, and equipment. As one of the companies whose core business is the distribution of mail, PT Pos has warehouses (or at least land) in business centers, and even small towns soon-to-be big cities. Similarly, cars and motorcycles as liaison between service points. While the equipment is ready for logistics operations include the following:

TABLE I.

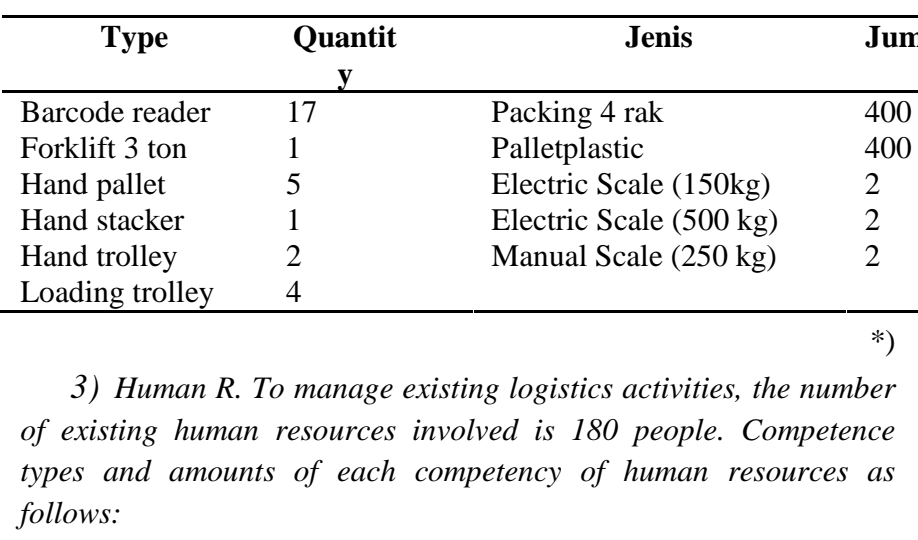

TABLE II

COMPETENCE OF EACH OF PT POS

\begin{tabular}{|c|c|c|c|c|}
\hline $\begin{array}{c}\text { Type of } \\
\text { competence }\end{array}$ & $\begin{array}{c}\text { Available } \\
\text { at the } \\
\text { Central } \\
\text { Office }\end{array}$ & $\begin{array}{c}\text { There } \\
\text { are large } \\
\text { branched }\end{array}$ & $\begin{array}{c}\text { available } \\
\text { spreads }\end{array}$ & Amount \\
\hline Distribution & 2 & 4 & 10 & 16 \\
\hline Warehousing & 3 & 8 & 6 & 17 \\
\hline $\begin{array}{l}\text { Ground } \\
\text { Handling }\end{array}$ & 1 & 4 & 40 & 45 \\
\hline $\begin{array}{l}\text { Regulated } \\
\text { Agent(RA) }\end{array}$ & 2 & - & - & 2 \\
\hline $\begin{array}{l}\text { Transportation } \\
\text { ( Trucking ) }\end{array}$ & 4 & 7 & 59 & 21 \\
\hline $\begin{array}{l}\text { Freight } \\
\text { Forwader }\end{array}$ & 4 & 6 & 10 & 20 \\
\hline $\begin{array}{l}\text { Customs } \\
\text { services }\end{array}$ & 1 & 4 & - & 5 \\
\hline SCM & 1 & 1 & 3 & 5 \\
\hline Total & 18 & 34 & 128 & 180 \\
\hline
\end{tabular}

Looking at the three profiles of these resources, PT Pos actually have a readiness to manage dedicated logistics business. The problem is how to utilize these resources to manage dynamic business.

\section{G. Assessment Application of the Object}

In general, the performance of the logistics industry is influenced by several factors; business processes, information technology, partnership and performance standards are called key success factors (KSF). With the consideration that any kind of business logistics and influence of different characteristics, it is necessary to be weighted, on each key success factors (KSF). Basis determining the proportion of each factor is assessed performed by Technical Consensus. The weightings for each factor can be seen in Tables 3 :
TABLE III.

WEIGHTING FOR FREIGHT FORWARDING

\begin{tabular}{|c|c|c|}
\hline KSF & Weight & Explanation \\
\hline Business Process & 40 & $\begin{array}{l}\text { HR with skill and } \\
\text { adequate knowledge of } \\
\text { freight forwarding is } \\
\text { required }\end{array}$ \\
\hline $\begin{array}{l}\text { Performance } \\
\text { Standard }\end{array}$ & 20 & $\begin{array}{l}\text { Service levels should be } \\
\text { established but have } \\
\text { relatively little influence } \\
\text { over business success. }\end{array}$ \\
\hline $\begin{array}{l}\text { Information } \\
\text { Technology }\end{array}$ & 10 & $\begin{array}{l}\text { Operations require simple } \\
\text { technological }\end{array}$ \\
\hline $\mathrm{h}^{\text {Relationship }}$ & 30 & $\begin{array}{l}\text { Relationships with long- } \\
\text { term carrier }\end{array}$ \\
\hline
\end{tabular}

2 TABLE IV. WEIGHTING FOR TRANSPORTING

KSF Weight

*) Business 40

Process

40 Vehicle, operation pattern, Vehicle, operation pattern,
competent human resources have the greatest effect on output.

Performance $30 \quad$ Standard travel time, the Standard condition of the goods being transported are vital to the success of the transportation business.

\begin{tabular}{lcl}
\hline $\begin{array}{l}\text { Information } \\
\text { Technology }\end{array}$ & 10 & $\begin{array}{l}\text { Relatively simple technology } \\
\text { can be used to support the } \\
\text { performance / output. }\end{array}$ \\
\hline Relationship & 20 & $\begin{array}{l}\text { Relationship with clients does } \\
\text { not always have to be long term. }\end{array}$ \\
\hline Total & 100 &
\end{tabular}

TABLE V.

WEIGHTING FOR WAREHOUSING

\begin{tabular}{lll}
\hline \multicolumn{1}{c}{ KSF } & Weight & \multicolumn{1}{c}{ Explanation } \\
\hline $\begin{array}{l}\text { Business } \\
\text { Process }\end{array}$ & 35 & $\begin{array}{l}\text { Availability of competent human } \\
\text { resources, adequate equipment, } \\
\text { warehouse facilities, SOPs that } \\
\text { clearly have the greatest } \\
\text { influence in the success of } \\
\text { warehousing services. }\end{array}$ \\
\hline $\begin{array}{l}\text { Performance } \\
\text { Standar }\end{array}$ & 10 & $\begin{array}{l}\text { Service levels should be } \\
\text { established and the relative } \\
\text { effect on business success. }\end{array}$ \\
\hline $\begin{array}{l}\text { Information } \\
\text { Technology }\end{array}$ & 25 & $\begin{array}{l}\text { Appropriate IT will support the } \\
\text { creation of warehousing } \\
\text { business process excellence. }\end{array}$ \\
\hline Relationship & 30 & $\begin{array}{l}\text { Long term (B2B business } \\
\text { relationship) }\end{array}$ \\
\hline Total & 100 & \multicolumn{2}{c}{} \\
\hline
\end{tabular}


TABLE VI

\begin{tabular}{ll}
\hline \multicolumn{1}{r}{ KSF } & Weight \\
\hline $\begin{array}{l}\text { Business } \\
\text { Process }\end{array}$ & 40
\end{tabular}

WEIGHTING FOR REGULATED AGENT

Business $\quad 40 \quad$ Availability of competent human

Process resources, adequate equipment, warehouse facilities, SOPs that clearly have the greatest influence in the success of Regulated Agent services

\begin{tabular}{lcc}
$\begin{array}{l}\text { Performance } \\
\text { Standar }\end{array}$ & 30 & $\begin{array}{l}\text { Service levels should be set high } \\
\text { and very influential to the } \\
\text { success of the business. }\end{array}$ \\
\hline $\begin{array}{l}\text { Information } \\
\text { Technology }\end{array}$ & 10 & $\begin{array}{l}\text { Relatively simple technology } \\
\text { can be used to support the } \\
\text { performance / output. }\end{array}$ \\
\hline Relationship & 20 & $\begin{array}{l}\text { Although the process is very } \\
\text { important business without } \\
\text { supported by a partnership that } \\
\text { both partners with the agent } \\
\text { regulared services can fail } \\
\text { because the basic concept is a } \\
\text { B2B business regulated agent } \\
\text { (long term relationship) }\end{array}$ \\
\hline
\end{tabular}

Total 100 $*)$

Based on the four tables above it can be seen that the business processes are a key success factor with the largest weight. To know the capabilities of each industry factor, an assessment needs to be done using a scale of 1 to 4 , which means the larger the scale the greater the acquired capabilities owned by PT Pos.

The assessment results are described as follows:

TABLE VII.

Key Success Scale
Factors

\begin{tabular}{lll}
\hline $\begin{array}{l}\text { Business } \\
\text { Process }\end{array}$ & 2 & $\begin{array}{l}\text { The experience is still not } \\
\text { enough because warehousing }\end{array}$
\end{tabular}

Process enough because warehousing service is still new at PT. Pos. although human resources have potential (Pos Logistics HR)

\begin{tabular}{|c|c|c|}
\hline $\begin{array}{l}\text { Performance } \\
\text { Standar }\end{array}$ & 2 & $\begin{array}{l}\text { Unestablished performance } \\
\text { measurement on managing } \\
\text { warehouse }\end{array}$ \\
\hline $\begin{array}{l}\text { Information } \\
\text { Technology }\end{array}$ & 2 & IT warehousing, \\
\hline Relationship & 2 & $\begin{array}{l}\text { Bargaining position for PT Pos } \\
\text { Indonesia in managing } \\
\text { warehouse is still weak }\end{array}$ \\
\hline
\end{tabular}

TABLE VIII.

TRANSPORTATION CAPABILITY ASSESSMENT SCALE

\begin{tabular}{lcl}
$\begin{array}{l}\text { Key Success } \\
\text { Factors }\end{array}$ & Scale & \multicolumn{1}{c}{ Explanation } \\
\hline $\begin{array}{l}\text { Business } \\
\text { Process }\end{array}$ & 2 & $\begin{array}{l}\text { Vehicle, operating patterns, } \\
\text { human resources owned by PT } \\
\text { Pos still need to be improved } \\
\text { although experienced }\end{array}$ \\
\hline $\begin{array}{l}\text { Performance } \\
\text { Standar }\end{array}$ & 1 & $\begin{array}{l}\text { The standard measure of travel } \\
\text { time, the condition of the goods to } \\
\text { be shipped are established. Needs } \\
\text { to be updated and followed up }\end{array}$
\end{tabular}

\begin{tabular}{lll}
\hline (Table VIII, cont.) & \\
\hline $\begin{array}{l}\text { Information } 3 \\
\text { Technology }\end{array}$ & $\begin{array}{l}\text { Relatively simple technology } \\
\text { (HP and fax), used to support } \\
\text { the performance / output. }\end{array}$ \\
\hline Relationship 11 & $\begin{array}{l}\text { Relationships with clients are } \\
\text { still very rarely bound by } \\
\text { contract }\end{array}$
\end{tabular}

TABLE IX

FREIGHT FORWARDING CAPABILITY ASSESSMENT SCALE

\begin{tabular}{lll}
$\begin{array}{l}\text { Key Success } \\
\text { Factors }\end{array}$ & Scale & \multicolumn{1}{c}{ Explanation } \\
\hline $\begin{array}{l}\text { Business } \\
\text { Process }\end{array}$ & 2 & $\begin{array}{l}\text { HR for PPJK owned, but needs } \\
\text { to be improved Custom } \\
\text { Terminal Depot and equipment } \\
\text { still needs to be improved }\end{array}$ \\
\hline $\begin{array}{l}\text { Performance } \\
\text { Standar }\end{array}$ & 1 & $\begin{array}{l}\text { Service levels have not been } \\
\text { clearly established and } \\
\text { followed, especially for } \\
\text { international shipments }\end{array}$ \\
\hline $\begin{array}{l}\text { Information } \\
\text { Technology }\end{array}$ & 3 & $\begin{array}{l}\text { Information technology-related } \\
\text { customs owned and can be } \\
\text { implemented }\end{array}$ \\
\hline Relationship & 2 & $\begin{array}{l}\text { Relationship with Gafeksi } \\
\text { implemented to facilitate the } \\
\text { handling of shipments abroad }\end{array}$ \\
& & \multicolumn{2}{l}{. }
\end{tabular}

TABLE X

Related AgEnt CAPability Assessment SCALE

\begin{tabular}{lll}
$\begin{array}{l}\text { Key Success } \\
\text { Factors }\end{array}$ & Scale & \multicolumn{1}{c}{ Explanation } \\
\hline $\begin{array}{l}\text { Business } \\
\text { Process }\end{array}$ & 1 & $\begin{array}{l}\text { HR prepared but dont possess } \\
\text { the ability to handle this } \\
\text { business yet. Still require } \\
\text { partnerships with both parties. }\end{array}$ \\
\hline $\begin{array}{l}\text { Performance } \\
\text { Standar }\end{array}$ & 1 & $\begin{array}{l}\text { Service levels have not been } \\
\text { clearly defined and not defined } \\
\text { performance measures on RA }\end{array}$ \\
\hline $\begin{array}{l}\text { Information } \\
\text { Technology }\end{array}$ & 2 & $\begin{array}{l}\text { Information technology is still } \\
\text { limited }\end{array}$ \\
\hline Relationship & 1 & $\begin{array}{l}\text { Relations with second party } \\
\text { have not been implemented }\end{array}$
\end{tabular}

Based on the feasibility assessment of the technical and operational aspects; as well as a descriptive analysis of the freight forwarding business, trasporting, warehousing and regulated agent; the element of the analysis described three corporate factors, there are: location, facilities \& infrastructure and Human Resources.

\section{CONCLUSIONS}

Referring to the assessment activities, literature study and SWOT analysis, the conclusions is:

Business opportunity and the customer needs are very huge. That aside, Logistic Business Unit has the potential to be the subsidiary, Post Logistics, by increasing its capability and its capacity. Capability and Capacity building is very important in preparing the company to face the fierce competition. 


\section{RECOMMENDATION}

Based on the above conclusions and overall research, the author suggests several recommendations, which are as follows:

- PT Pos needs to conduct an assessment of the business to focus on formulating the main business resource it needs. This assessment is necessary in order to achieve effectiveness and efficiency of resources.

- Establishing a collaboration with business partners if need be.

- The subsidiary will have to focus on a particular segment which meets its logistics competence.

\section{REFERENCES}

[1] Booz \& Company, Fact Finding onFinal Report to PT Pos Indonesia, 2010.

[2] Ella Syafputri. Kadin: biaya logistik di Indonesia paling mahal. Februari 14 http://www.antaranews.com/berita/1329201790/kadin-biayalogistik-di-indonesia-paling-mahal (diakses 12 Oktober 2012).

[3] BPS. Berita Resmi Statistik No. 13/02/Th. XV. Jakarta: BPS, 2012

[4] Law no 38, on Postal services, 2009.

[5] Frost \& Sullivan, Research on Logistics, 2011.

[6] Teece, David J., Gary Pisano, dan Amy Shuen. "Dynamic Capabilities and Strategic Management." Strategic Management Journal, Vol. 18 No. 7, 1997: 509-533.

[7] Eisenhardt, Kathleen M. dan Jefrey A. Martin. "Dynamic Capabilities: What are they?" Strategic Management Journal, Vol. 21, 2000: 1105-1121.

[8] Wernerfelt, B. "The Resource-based View of the Firm." Strategic Management Journal, Vol. 5, 1984: 171-180.

[9] Barney, Jay B. "Organizational Culture: Can It Be a Source of Sustained Competitive Advantage?" The Academy of Management Review, Vol. 11 No. 3, 1986: 656-665.

[10] Helfat, Constance E. dan Margaret A. Peteraf. "Understanding dynamic capabilities: progress along a developmental path." Strategic Organization, Vol. 7 No. 1, 2009: 91-102.

[11] Barney, Jay. "Firm Resources and Sustained Competitive Advantage." Journal of Management, Vol. 17 No. 1, 1991: 99120.

[12] Eisenhardt, Kathleen M. dan Jefrey A. Martin. "Dynamic Capabilities: What are they?" Strategic Management Journal, Vol. 21, 2000: 1105-1121.

[13] Saura, Irene Gil, David Servera Frances, Gloria Berenguer Contri dan Maria Fuentes Blasco. "Logistics service quality: a new way to loyalty." Industrial Management \& Data System, Vol. 108 No. 5, 2008: 650-668.

[14] Porter, Michael E. "Competitive Advantage: Creating and Sustaining Superior Performance." New York, The Free Press, 1985.
[15] Cho, Jay Joong-Kun, John Ozment dan Harry Sink. "Logistics capability, logistics outsourcing and firm performance in an ecommerce market." International Journal of Physical Distribution \& Logistics Management, VOl. 38 No. 5, 2007: 336-359.

[16] Stock, James R. dan Douglas M. Lambert. Strategic Logistics Management, edisi ke-4. NJ: McGraw-Hill, 2001.

[17] Mentzer, John T., Roger Gomes dan Robert E. Krapfel. "Physical Distribution Service: A Fundamental Marketing Concept?" Journal of the Academy of Marketing Science, VOl. 17 No. 1, 1989: 53-62.

[18] Mentzer, John T., Metthew B. Myers dan Mee-Shew Cheung. "Global market segmentation for logistics services." Industrial Marketing Management, Vol. 33, 2004: 15-20.

[19] Mentzer, John T., Daniel J. Flint dan G. Tomas M. Hult. "Logistics Service Quality as a Segment-Customized Process." Journal of Marketing, Vol. 65, 2001: 82-104.

[20] Ellinger, Alexander E. "Improving Marketing/Logistics CrossFunctional Collaboration in the Supply Chain." International Marketing Management, Vol. 29, 2000: 85-96.

[21] Rafiq, Muhammed dan Harlina S. Jaafar. "Measuring Customers' Perceptions of Logistics Service Quality of 3PL Service Providers." Journal of Business Logistics, Vol. 28 No. 2 , 2007: 159-175.

[22] Stalk, George, Philip Evans dan Lawrence E. Shulman. "Competing on capabilities: The new rules of corporate strategy." Harvard Business Review, Vol. 70 No. 2, 1992: 5769.

[23] Bolton, Ruth N., Katherine N. Lemon dan Peter C. Verhoef. "The Theoretical Underpinnings of Customer Asset Management: A Framework and Propositions for Future Research." Journal of the Academy of Marketing Science, Vol. 32 No. 3, 2004: 271-292.

[24] Lam, Shun Yin, Venkatesh Shankar dan M. Khrisna Erramilli. "Custmer Value, Satisfaction, Loyalty, adn Switching Cost: An Illustration From a Businesss-to-Business Service Context." Journal of the Academy Marketing Science, Vol. 32 No. 3, 2004: 293-311.

[25] Maklan, Stan dan Simon Knox. "Dynamic capabilities: the missing link in CRM investments." European Journal of Marketing, Vol. 43 No. 11/12, 2009: 1392-1410.

[26] Jiao, Jianxin dan Chun-Hsien Chen. "Customer Requirement Management in Product Development: A Review of Research Issues." Concurrent Engineering, Vol. 14 No. 3, 2006: 173-184.

[27] Peraault, William D. dan Frederick Russ. "Physical Distribution Service: A Neglected Aspect of Marketign Maagement." MSU Business Topics, Vol. 22 No. 2, 1974: 43-64.

[28] Robert E. Krapfel. "Physical Distribution Service: A Fundamental Marketing Concept?" Journal of the Academy of Marketing Science, VOl. 17 No. 1, 1989: 53-62.

[29] World Bank. Connecting to Compete 2012: Trade Logistics in the Global Economy. Washington: The World Bank, 2012. 